\title{
Overnachten in een politiecel
}

Citation for published version (APA):

Geijsen, K., Kop, N., \& de Ruiter, C. (2018). Overnachten in een politiecel: Een onderzoek naar het psychisch welzijn en slaapproblemen van verdachten. Tijdschrift voor Criminologie, 60(3), 312-326. https://doi.org/10.5553/TvC/0165182X2018060003003

Document status and date:

Published: 01/01/2018

DOI:

10.5553/TvC/0165182X2018060003003

Document Version:

Publisher's PDF, also known as Version of record

Document license:

Taverne

Please check the document version of this publication:

- A submitted manuscript is the version of the article upon submission and before peer-review. There can be important differences between the submitted version and the official published version of record.

People interested in the research are advised to contact the author for the final version of the publication, or visit the DOI to the publisher's website.

- The final author version and the galley proof are versions of the publication after peer review.

- The final published version features the final layout of the paper including the volume, issue and page numbers.

Link to publication

\footnotetext{
General rights rights.

- You may freely distribute the URL identifying the publication in the public portal. please follow below link for the End User Agreement:

www.umlib.nl/taverne-license

Take down policy

If you believe that this document breaches copyright please contact us at:

repository@maastrichtuniversity.nl

providing details and we will investigate your claim.
}

Copyright and moral rights for the publications made accessible in the public portal are retained by the authors and/or other copyright owners and it is a condition of accessing publications that users recognise and abide by the legal requirements associated with these

- Users may download and print one copy of any publication from the public portal for the purpose of private study or research.

- You may not further distribute the material or use it for any profit-making activity or commercial gain

If the publication is distributed under the terms of Article $25 \mathrm{fa}$ of the Dutch Copyright Act, indicated by the "Taverne" license above, 


\title{
Overnachten in een politiecel
}

\section{Een onderzoek naar het psychisch welzijn en slaapproblemen van verdachten}

\author{
Koen Geijsen, Nicolien Kop \& Corine de Ruiter
}

In dit onderzoek werd de invloed van de omgeving van een politiecellencomplex op het psychologisch welzijn en slaapproblemen van verdachten onderzocht. Resultaten tonen aan dat verdachten in een politiecel een verminderd psychologisch welzijn ervaren, dat zij slechter slapen, en dat een verminderd psychisch welzijn is gerelateerd aan slaapproblemen. Consequenties van het verblijf in politiecellencomplexen voor het psychisch welzijn en de slaapproblemen van verdachten, alsmede richtingen voor verder onderzoek naar omstandigheden in politiecellencomplexen, worden besproken.

\section{Introductie}

In de afgelopen jaren is steeds meer onderzoek gedaan naar de invloed van de omgeving op gedrag en psychisch welzijn van mensen. Onderzoek heeft onder meer uitgewezen dat als mensen de omgeving waarin zij zich bevinden als stressvol ervaren, negatieve prestaties en negatieve emoties toenemen (Bell e.a., 2001). Dit is onder andere aangetoond in psychiatrische instellingen (Karlin \& Zeiss, 2006), ziekenhuizen (Drahota e.a., 2012; Dijkstra e.a., 2006) en gevangenissen (Hancock \& Jewkes, 2011; Morris \& Worrall, 2010). Het ontwerp van gevangenissen is bijvoorbeeld van invloed op het gedrag en emoties van gevangenen (Bell e.a., 2001). Gedrag van gevangenen blijkt gerelateerd te zijn aan factoren als interieur, architectuur en sociale omstandigheden (Steinke, 1991). Ook temperatuur, kleuren, drukte, kwaliteit van de lucht en de hoeveelheid daglicht zijn gerelateerd aan stress en problematisch gedrag onder gevangenen (Morris e.a., 2012; Steinke, 1991). Verder leidt gebrek aan mentale stimulatie door opsluiting op den duur tot stress, boosheid en frustratie, en heeft een negatieve relatie met gevangenispersoneel een negatieve invloed op het psychisch welzijn van gevangenen (Nurse e.a., 2003; Steinke, 1991).

Tot nu toe is nog weinig onderzoek gedaan naar de invloed van het verblijf in een politiecellencomplex op het psychisch welzijn en slaapproblemen van verdachten. Daar gaat dit onderzoek over.

\section{Omgevingspsychologie}

Omgevingspsychologen maken gebruik van verschillende theoretische modellen om de invloed van de omgeving op psychisch welzijn en gedrag van mensen te verklaren. Hoewel de verschillende modellen zich vaak richten op een specifieke omgeving, vertonen zij veel overeenkomsten (Gifford e.a., 2011). Bijvoorbeeld: bij de stimulatietheorie is het uitgangspunt dat mensen zich tot op een bepaald 


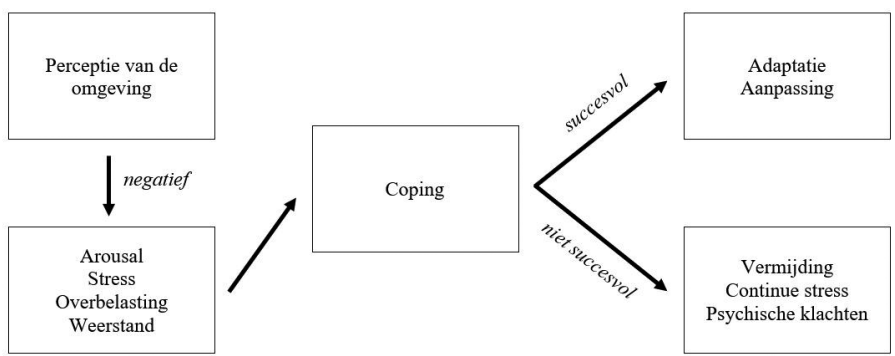

Figuur 1 Theoretisch (eclectisch) model van Bell e.a. (2001) over de invloed van de omgeving op gedrag en emoties van mensen (hier vereenvoudigd weergegeven)

niveau aanpassen aan hun omgeving en wanneer mensen onder- of overstimulatie vanuit de omgeving ondervinden, zij verhoogde niveaus van arousal en stress ervaren (Gifford e.a., 2011; Wohlwill, 1966). De controletheorie legt een ander accent, hierin staat namelijk het vermogen van de persoon om stimuli van de omgeving te controleren centraal (Altman, 1975; Gifford e.a., 2011). De integrale benadering, zoals het interactionisme en organische modellen, probeert een compleet beeld te beschrijven van de complexe interactie tussen personen en hun omgeving (Altman \& Rogoff, 1987; Gifford e.a., 2011).

Bell e.a. (2001) combineerden verschillende theoretische modellen in een eclectisch model van theoretische perspectieven hoe de omgeving emoties en gedrag van mensen beïnvloedt. In hun model is de aanname dat mensen op verschillende manieren de omgeving waarnemen. Als er voldoende copingvaardigheden zijn, wordt gedrag succesvol aangepast aan de eisen van de omgeving, met op de lange duur als bijeffect een groter zelfvertrouwen en ontwikkeling van vaardigheden. Als de omgeving echter op een negatieve manier wordt waargenomen door onderstimulatie (tekort aan stimuli) of overstimulatie (te veel stimuli) en copingvaardigheden tekortschieten, dan leidt dit tot vermijdend gedrag en aanhoudende spanning en stress, met mogelijk een verminderd psychisch welzijn, zogenaamde aangeleerde hulpeloosheid en/of verminderde prestaties tot gevolg (Bell e.a., 2001). Het model van Bell e.a. (2001) is vereenvoudigd weergegeven in figuur 1.

\section{Nederlandse politiecellencomplexen}

Per jaar worden in Nederland ongeveer 240.000 mensen ingesloten in politiecellencomplexen (Inspectie Veiligheid en Justitie, 2015), meestal verdachten die zijn aangehouden door de politie op verdenking van een overtreding of misdrijf. Afhankelijk van de ernst van het delict en de omvang van het opsporingsonderzoek is het nodig dat verdachten gedurende een bepaalde tijd beschikbaar blijven voor het politieonderzoek. Dit varieert van enkele uren tot een aantal dagen, bijvoorbeeld omdat er eerst getuigen moeten worden gehoord, ander bewijs moet worden verzameld, of dat een verdachte meerdere keren moet worden verhoord. 
Blaauw e.a. (1997) onderzochten de kwaliteit van Nederlandse politiecellencomplexen en kwamen destijds tot de conclusie dat deze erg van elkaar verschilden qua inrichting, procedures, het aantal arrestantenverzorgers per aantal verdachten en faciliteiten, zoals de beschikbaarheid van een verpleegkundige. Zij constateerden dat de fysieke condities in politiecellencomplexen meestal minder goed zijn in vergelijking met reguliere gevangenissen, bijvoorbeeld voor wat betreft grootte en inrichting van cellen, de mogelijkheid tot contact met familie, vrienden en andere arrestanten, de gelegenheid tot dagbesteding en de mate van drukte en lawaai. Nederlandse politiecellencomplexen zijn voornamelijk ontworpen en ingericht met het oog op functionaliteit en veiligheid, niet specifiek op het comfort van verdachten (Blaauw e.a., 1997).

In de afgelopen jaren is enige verandering zichtbaar. Tegenwoordig moet de inrichting voldoen aan strenge nationale regelgeving (Regeling politiecellencom$\mathrm{plex}^{1}$ ) en internationale regelgeving (zie Hagens, 2011, voor een beschrijving). Alle politiecellen zijn vanuit het oogpunt van hygiëne en veiligheid uitgerust met een plastic matras en hoofdkussen, een wollen deken en papieren lakens. In sommige politiecellencomplexen is het inmiddels voor verdachten mogelijk om zelf licht, toilet en verwarming te bedienen, en zijn cellen soms uitgerust met een zogenaamde informatiezuil voorzien van een tv, radio en/of gameconsole. Dat is niet overal het geval. Regels verschillen per politiecellencomplex op het gebied van hoe vaak en hoelang verdachten mogen roken, op de luchtplaats mogen verblijven, en of er op verzoek een extra deken of maaltijd wordt verstrekt. Soms blijft in de cel 's nachts een kleine lamp branden, zodat arrestantenverzorgers via een inspectieluik in de celdeur de toestand van verdachten in de gaten kunnen houden, maar het komt ook voor dat arrestantenverzorgers 's nachts ter controle met een zaklamp op verdachten schijnen. Vaak is het in politiecellencomplexen lawaaierig, ook's nachts, vanwege geagiteerde, agressieve en verwarde verdachten en het insluiten van verdachten.

\section{Slaapproblemen}

Als verdachten slaapproblemen ervaren, kan dat negatief van invloed zijn tijdens het politieverhoor (Gudjonsson, 2003; Harrison \& Horn, 2000). Uit onderzoek is bekend dat slaapproblemen een negatief effect hebben op cognitieve vermogens en vaardigheden (Ratcliff \& Van Dongen, 2009), zoals alertheid, reactietijd en besluitvorming (Kilgore e.a., 2006), en leidt het tot disoriëntatie, een verminderd beslissingsvermogen en verwardheid (Gudjonsson, 2003; Harrison \& Horne, 2000). Ook is aangetoond dat slaapproblemen symptomen van psychische stoornissen kunnen verergeren (Baksheev e.a., 2012; Blaauw e.a., 1998).

Een voorbeeld van onderzoek naar de invloed van slaapproblemen op cognitie is het experiment van Killgore en collega's (2006), die het effect van slaaponthouding testten op het vermogen om beslissingen te nemen onder onzekere omstandigheden. Zij deden dit met behulp van de Iowa Gambling Task (IGT), een computergoktest met kaarten, waarbij steeds één kaart moet worden gekozen van vier stapels kaarten. De proefpersoon kan kiezen tussen een onmiddellijke grote belo- 
ning samengaand met een hoge kans op verlies en een kleinere beloning op langere termijn met een lager risico op verlies. Resultaten op de IGT toonden aan dat slaaponthouding het vermogen om gunstige beslissingen voor de lange termijn te nemen negatief beïnvloedt, omdat vermoeide proefpersonen veel risico namen en daardoor veel geld verloren.

Het onderzoek van Thomas e.a. (2000) liet zien dat slechts één nacht zonder slaap al een negatieve invloed heeft op alertheid en hogere cognitieve processen, zoals plannen, organiseren en informatieverwerking. Dat slaapproblemen ook direct in verband staan met valse bekentenissen toonden Frenda e.a. (2016) aan in een experimentele studie. Proefpersonen $(\mathrm{N}=88)$ moesten een computertest uitvoeren, waarbij hun werd verteld dat zij absoluut niet op de escapetoets mochten drukken, omdat anders gegevens verloren zouden gaan. Vervolgens werd de groep in tweeën verdeeld, waarna de ene groep $(n=44)$ nachtrust kreeg en de andere groep $(n=44)$ de hele nacht wakker werd gehouden. De volgende ochtend werden de proefpersonen verhoord, waarbij hun vooraf werd verteld dat ze toch op de escapeknop hadden gedrukt - wat in werkelijkheid niet was gebeurd. Uit de resultaten van dit experiment bleek dat 68 procent $(n=30)$ van de proefpersonen die niet geslapen hadden een valse bekentenis deed en verklaarde inderdaad op de escapeknop te hebben gedrukt, in vergelijking met 36 procent $(n=16)$ van de proefpersonen die wel geslapen hadden (Frenda e.a., 2016).

Kortom, verdachten die slaapproblemen ervaren, zijn minder goed in staat weloverwogen beslissingen te nemen (Harrison \& Horne, 2000) en zijn tijdens een politieverhoor meer beïnvloedbaar (Blagrove, 1996; Frenda e.a., 2016; Gudjonsson, 2003).

\section{Onderzoeksvragen en hypothesen}

De hierboven beschreven theorie en empirische studies doen de vraag rijzen op welke manier het verblijf in een politiecellencomplex van invloed is op het psychisch welzijn en slaapproblemen van verdachten. Daarnaast is de vraag in welke mate slaapproblemen samenhangen met het psychisch welzijn van verdachten, en of er verschillen zijn in de mate van psychisch welzijn en slaapproblemen tussen verdachten die thuis hebben geslapen en verdachten die in een politiecellencomplex geslapen hebben.

Deze vragen leveren een vijftal hypothesen op, namelijk dat (1) verdachten in een politiecellencomplex een verminderd psychisch welzijn en (2) een hogere mate van slaapproblemen ervaren in vergelijking tot de algemene bevolking, dat (3) slaapproblemen bij verdachten negatief samenhangen met psychisch welzijn, en dat verdachten die in een politiecel overnachten (4a) een verminderd psychisch welzijn en (4b) meer slaapproblemen ervaren dan verdachten die thuis overnachten (Baksheev e.a., 2012; Blaauw e.a., 1998; Blagrove, 1996; Gudjonsson, 2003; Harrison \& Horne, 2000). 


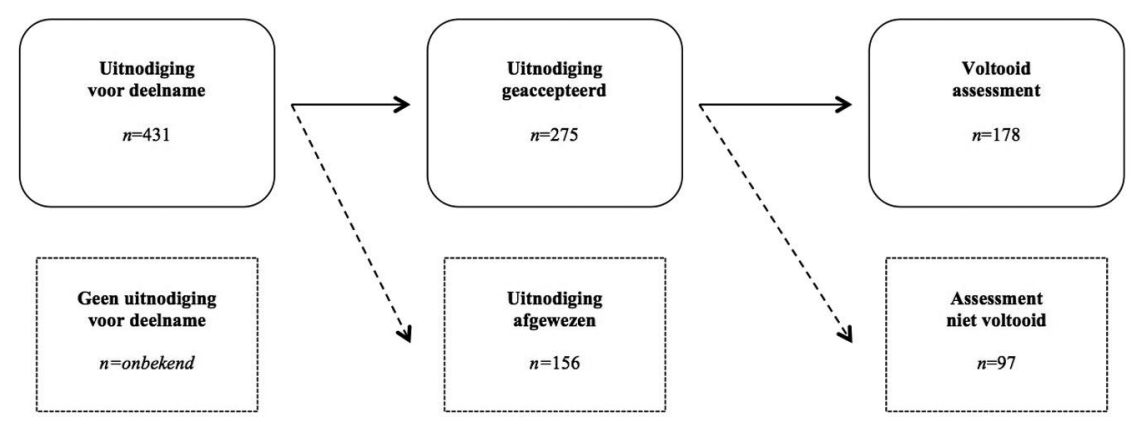

Figuur 2 Schema van de wervingsprocedure voor deelname aan het psychologisch onderzoek

\section{Methode}

\section{Deelnemers}

De deelnemers aan dit onderzoek waren verdachten die in een Nederlands politiecellencomplex verbleven. De psychologische onderzoeken vonden plaats tussen 24 juni 2014 en 7 mei 2015. Alleen verdachten die 18 jaar of ouder waren en de Nederlandse taal voldoende machtig waren, werden uitgenodigd om aan het psychologisch onderzoek deel te nemen, waarbij vooraf niet kon worden geselecteerd op bijvoorbeeld het soort misdrijf of de duur van het verblijf in het politiecellencomplex. Als een verdachte in een observatiecel was geplaatst (bijvoorbeeld vanwege ernstige fysieke en/of psychische problemen, of drugsgebruik), of als er zicht was op vrijlating op korte termijn, werd hij of zij niet uitgenodigd voor deelname. Ook werden alleen verdachten uitgenodigd die in verzekering waren gesteld (zij verbleven maximaal voor drie dagen en vijftien uur in het cellencomplex). De psychologische onderzoeken duurden gemiddeld een uur tot anderhalf uur.

Een aantal psychologische onderzoeken moest worden gestaakt vanwege taalproblemen, waardoor het afnemen van vragenlijsten onmogelijk was ( $n=63)$, vanwege onverwachte ontwikkelingen in het opsporingsonderzoek (zoals onaangekondigde verhoren, bezoek van de raadsman of een plotselinge invrijheidstelling; $\mathrm{n}=21$ ), of omdat de deelnemer direct na de start van het onderzoek meldde dat zij/hij last had van psychotische symptomen (zoals visuele en/of akoestische hallucinaties) of ernstige depressieve symptomen ( $n=13)$. Uiteindelijk namen 178 verdachten vrijwillig deel aan het onderzoek: 37 in Amsterdam, 35 in Breda, 31 in Eindhoven, 26 in Heerlen, 8 in Tilburg en 41 in Maastricht. De leeftijd van de deelnemers varieerde van 18 tot 63 jaar $(M=31.7, S D=11.2, M d n=27.5)$. De wervingsprocedure is weergegeven in figuur 2 en de demografische gegevens van de deelnemers zijn weergegeven in tabel 1. 
Tabel 1 Demografische gegevens van de deelnemers aan het onderzoek $(N=178)$

\begin{tabular}{l|r|r|}
\hline & $\mathbf{n}$ & \multicolumn{1}{|c|}{$\%$} \\
\hline Geslacht & 13 & 8,7 \\
\hline Vrouw & 136 & 91,3 \\
\hline Man & & \\
\hline Opleiding & 49 & 32,9 \\
\hline Basisschool/speciaal onderwijs & 83 & 55,7 \\
\hline Havo/vwo/mbo & 17 & 11,4 \\
\hline Hbo/universiteit & & 91,3 \\
\hline Nationaliteit & 136 & 16,8 \\
\hline Nederlands & 25 & 8,7 \\
\hline Nederlands en een tweede nationaliteit & 13 & 61,8 \\
\hline Andere dan de Nederlandse nationaliteit & & 38,2 \\
\hline Beroep & 110 & \\
\hline Werkloos & 68 & \\
\hline In loondienst of zelfstandige & & \\
\hline
\end{tabular}

Het is niet mogelijk te achterhalen hoeveel verdachten in totaal in de politiecellencomplexen verbleven tijdens de onderzoeksperiode. Sommige verdachten verbleven namelijk slechts voor een paar uur in een cellencomplex omdat zij bijvoorbeeld niet in voorlopige hechtenis werden gesteld, dan wel vanwege vreemdelingenbewaring, of vanwege een kort verblijf wegens openstaande boetes of in afwachting van transport naar een huis van bewaring. Het was ook niet mogelijk om na te gaan hoeveel uren de deelnemers in een politiecellencomplex verbleven.

\section{Procedure}

De psychologische onderzoeken werden verricht door de eerste auteur, als basispsycholoog in bezit van de Basisaantekening Psychodiagnostiek (BAPD), ten tijde van het onderzoek lid van het Nederlands Instituut van Psychologen (NIP) en niet werkzaam bij de politie. Hij werd geassisteerd door drie tweedejaars masterstudenten Forensische Psychologie van de Universiteit Maastricht, die diverse mastercursussen met betrekking tot psychodiagnostiek succesvol hadden afgerond en gedurende de onderzoeksperiode intensief werden begeleid. De studenten ondergingen vooraf een veiligheidsonderzoek door de Politieacademie en tekenden een geheimhoudingsverklaring.

Verdachten werden in hun cel benaderd of zij wilden deelnemen aan het onderzoek. Als een verdachte daarmee instemde, werd hij/zij meegenomen naar een aparte ruimte (een verhoorkamer of een advocatenkamer), waar de opzet van het onderzoek nader werd uitgelegd. Alle potentiële deelnemers werd verteld dat zij alleen anoniem konden deelnemen, dat de resultaten van het onderzoek op geen enkele manier konden worden gebruikt in een opsporingsonderzoek, en dat de 
onderzoekers als psycholoog (i.o.) waren gebonden aan een geheimhoudingsplicht. Tot slot werd het informed-consentformulier uitgelegd en gevraagd te ondertekenen, en werd aan potentiële deelnemers verzekerd dat zij hun deelname te allen tijde konden beëindigen zonder opgaaf van reden.

Dit onderzoek is vooraf goedgekeurd door de Ethical Review Committee Psychology and Neuroscience van Maastricht University (ERCPN-nummer: 03_10_2014), het College van procureurs-generaal van het Openbaar Ministerie en de korpschef van de Nationale Politie.

\section{Instrumenten}

De hierna beschreven instrumenten maakten deel uit van een psychologische testbatterij om verschillende psychologische kwetsbaarheden te onderzoeken.

Om simulatie (malingering) van symptomen uit te sluiten werd een verkorte vorm van de Wildman Symptom Checklist (WSC; Wildman \& Wildman, 1999) gebruikt. De verkorte WSC bevat vier items die ernstige, maar niet-geloofwaardige, cognitieve symptomen beschrijven. Eerder onderzoek wees uit dat deze vier items een goede voorspeller van malingering zijn (Merckelbach e.a., 2008; 2014). Een voorbeeld van een WSC-item is: 'Ik heb soms zo'n erge hoofdpijn dat mijn voeten er zeer van doen.' De items worden gescoord op een vijfpunts-Likertschaal (van $0=$ helemaal niet tot $4=$ extreem). De totaalscore is de somscore van de vier items, variërend van 0 tot 16, waarbij een score van 4 of hoger een indicatie geeft voor simulatie. In eerdere onderzoeken werd een Cronbach's alpha tussen .56 en .73 gevonden (Deetman e.a., 2011); in dit onderzoek was de Cronbach's alpha .73.

Psychisch welzijn werd ten eerste gemeten aan de hand van de totale schaal Psychoneuroticisme van de Symptom Checklist 90 (SCL-90, Derogatis, 1977; Nederlandse versie: SCL-90-R-NL, Arrindell \& Ettema, 2005). De SCL-90-R-NL is een gevalideerd instrument voor het meten van psychische klachten en geeft een indruk van psychische lijdensdruk (Arrindell \& Ettema, 2005). De vragenlijst bevat 90 items die worden gescoord op een vijfpunts-Likertschaal, lopend van 1 'helemaal niet' tot 5 'heel erg'. Daarnaast werd psychisch welzijn gemeten aan de hand van een negatief affect (Watson e.a., 1988), waarvoor de Depression, Anxiety, and Stress Scale (depressie, angst en stress schaal; DASS) werd gebruikt. De DASS geeft een beeld van subjectief ervaren negatieve emoties (DASS; Lovibond \& Lovibond, 1995; Nederlandse versie: De Beurs e.a., 2001). De subschaal Depressie meet symptomen als weinig initiatief, pessimisme over de toekomst en afwezigheid van interesse. De subschaal Angst meet symptomen als paniek, droge mond, angst om slecht te presteren en tremoren. De subschaal Stress meet symptomen als spanning, niet tot rust kunnen komen, irritatie en opvliegendheid (De Beurs e.a., 2001). Voor dit onderzoek werd de verkorte, 21-itemsversie gebruikt, die zeven items per subschaal bevat. De items kunnen worden gescoord op een schaal van 0 (nooit) tot 3 (meestal). De somscores van de subschalen worden vermenigvuldigd met twee om de scores van de 21-itemsversie te kunnen vergelijken met de oorspronkelijke 42 items van de DASS (De Beurs e.a., 2001).

Slaapproblemen werden gemeten met de subschaal Slaapproblemen van de SCL-90-R-NL en met zelfrapportage met behulp van twee zelfgeconstrueerde items. De subschaal Slaapproblemen bevat drie items, namelijk over moeilijk in 
slaap kunnen vallen, te vroeg wakker worden en een gestoorde of onrustige slaap (Arrindell \& Ettema, 2005). Verder werd de vraag gesteld: 'Hoe heeft u de afgelopen nacht geslapen, op een schaal van 1 tot 10, waarbij 1 heel slecht en 10 heel goed is?' En daarna: 'Heeft u hier in het cellencomplex geslapen?', waarop ja of nee geantwoord kon worden.

\section{Data-analyse}

De scores op de SCL-90-R-NL en de DASS werden vergeleken met scores van normgroepen uit eerder onderzoek (respectievelijk uit de handleiding van de SCL-90-R-NL, Arrindell \& Ettema, 2005, en uit het validatieonderzoek van de DASS, De Beurs e.a., 2001), verschillen werden onderzocht met behulp van ANOVA's en Tukey post-hoc tests. Verschillen tussen psychisch welzijn en slaapproblemen tussen verdachten die op het politiebureau en thuis hadden geslapen werden berekend met t-toetsen en post hoc onderzocht met een poweranalyse. Correlatie tussen psychisch welzijn en slaapproblemen werd berekend aan de hand van correlatiecoëfficiënt Pearson's r. Alle analyses werden verricht met IBM SPSS versie 24 - behalve de poweranalyse, deze werd berekend met het programma G*Power (Faul e.a., 2007).

\section{Resultaten}

Voorafgaand aan de analyses werden de verdachten ( $\mathrm{N}=178)$ met behulp van de WSC onderzocht op simulatie. In veertien gevallen scoorden deelnemers boven de afkapwaarde en in vijftien gevallen ontbraken resultaten op dit instrument. De resultaten van deze 29 deelnemers werden buiten beschouwing gelaten bij verdere analyses, zodat uiteindelijk 149 deelnemers overbleven. Verder bleken scores van de totale schaal Psychoneuroticisme en de subschaal Slaapproblemen van de SCL-90-R-NL, alsmede scores van de subschalen Depressie, Angst en Stress van de DASS normaal verdeeld te zijn.

De gemiddelde score op de totale schaal Psychoneuroticisme van de SCL-90-R-NL was in dit onderzoek 151.2 ( $\mathrm{SD}=47.2)$. Eerder werd in een steekproef uit de normale Nederlandse bevolking $(\mathrm{N}=2.394)$ een gemiddelde score van 118.3 $(\mathrm{SD}=32.4)$ gevonden, en in een steekproef onder Nederlandse gedetineerden in een reguliere gevangenis ( $N=257$ ) een gemiddelde score van 153.1 ( $S D=52.0)$. Deze scores verschilden significant van elkaar, $\mathrm{F}(2,1432)=114.83, \mathrm{p}=.000$. Tukey post-hoc tests toonden aan dat alleen de scores van de steekproef van dit onderzoek en die van gedetineerden niet van elkaar verschilden, $\mathrm{p}>.05$.

Scores op de subschalen Depressie, Angst en Stress van de DASS zijn weergegeven in tabel 2, waarbij ook de gemiddelde scores zijn weergegeven die in eerder onderzoek werden gevonden in een klinische steekproef (ambulante patiënten van een psychiatrische kliniek; $\mathrm{N}=173$ ) en in een steekproef uit de normale Nederlandse bevolking (studenten; $\mathrm{N}=289$ ). Er werden significante verschillen gevonden voor de subschalen Depressie, $F(2,608)=41.50$, $p=.000$; Angst, $F(2,608)=56.27, p=.000$ en Stress, $\mathrm{F}(2,608)=39.50, \mathrm{p}=.000$. Tukey post-hoc tests toonden aan dat de scores tussen de drie steekproeven significant verschilden, p's<.01 - met uitzonde- 
Tabel 2 Scores (gemiddelden en standaarddeviaties) van de subschalen van de DASS van verdachten die in politiecellencomplexen verbleven, een klinische populatie en de normale bevolking

\begin{tabular}{|c|c|c|c|}
\hline & $\begin{array}{l}\text { Verdachte }{ }^{a} N=149 \\
\text { M (SD) }\end{array}$ & $\begin{array}{l}\text { Klinische populatie }^{b} \\
\text { N=I73 M (SD) }\end{array}$ & $\begin{array}{l}\text { Normale populatie } \\
\mathrm{N}=289 \text { M (SD) }\end{array}$ \\
\hline Depressie & II.6 (9.4)* & I3.4(II.9) & $5.7(7.7)^{*}$ \\
\hline Angst & $9.2(7.4)^{*}$ & $11.7(10.1)^{*}$ & $4.2(5.9)^{*}$ \\
\hline Stress & I $2.3(7.9)^{*}$ & I5.7 (I0.2)* & $8.4(8.0)^{*}$ \\
\hline
\end{tabular}

* $\mathrm{p}<.05$, tweezijdig getoetst.

a Dit onderzoek.

b De Beurs e.a., 2001.

ring van de subschaal Depressie; de score van dit onderzoek verschilde niet met de score van de klinische steekproef, $\mathrm{p}=.21$.

De gemiddelde score op de subschaal Slaapproblemen van de SCL-90-R-NL was $6.6(S D=3.0)$, terwijl eerder in een steekproef uit de normale Nederlandse bevolking $(\mathrm{N}=2.394)$ een score van $4.5(\mathrm{SD}=2.2)$ werd gevonden, en in een steekproef $(\mathrm{N}=257)$ van Nederlandse, mannelijke gedetineerden in reguliere gevangenissen een score van 7.1 ( $S D=3.8$ ). De scores tussen de drie steekproeven bleken significant van elkaar te verschillen, $\mathrm{F}(2,2797)=172.65, \mathrm{p}=.000$. Tukey post-hoc tests lieten zien dat de score gevonden in dit onderzoek en de score van de steekproef van gedetineerden niet significant van elkaar verschilden, $p=.11$. Verder was het gemiddelde cijfer dat verdachten gaven voor de ervaren kwaliteit van slaap van de nacht voorafgaand aan het psychologisch onderzoek een 4.7 op een schaal van 1 tot $10(\mathrm{SD}=2.18)$.

Daarna bleek dat slaapproblemen gemeten aan de hand van zowel de subschaal Slaapproblemen van de SCL-90-NL als zelfrapportage negatief correleerden met psychisch welzijn (totale schaal Psychoneuroticisme SCL-90-R-NL en de DASS), met uitzondering van de subschaal Stress van de DASS. De correlaties tussen de verschillende schalen zijn weergegeven in tabel 3. Er werd geen Bonferroni-correctie toegepast om Type II-fouten (fout-negatief) te voorkomen, vanwege het exploratieve karakter van dit onderzoek (Field, 2012).

Tot slot is gekeken naar verschillen in psychisch welzijn en slaapproblemen tussen verdachten die de nacht voorafgaand aan het psychologisch onderzoek thuis hadden geslapen ( $n=15 ; 12$ mannen en 3 vrouwen; leeftijd $M=29.9 ; S D=12.4$; $\mathrm{Mdn}=25.0)$ en in een politiecellencomplex hadden geslapen ( $\mathrm{n}=134 ; 124$ mannen en 10 vrouwen; leeftijd $M=32.0 ; S D=10.8 ; M d n=28.5)$. T-toetsen toonden aan dat scores tussen de twee groepen (thuis geslapen vs. in een politiecellencomplex geslapen) significant verschilden met betrekking tot Psychoneuroticisme, Depressie, Angst en de zelfgerapporteerde kwaliteit van slaap, maar niet met betrekking tot Slaapproblemen en Stress. De gemiddelde scores van verdachten die thuis en in een cel hadden geslapen en de resultaten van de t-toetsen zijn weergegeven in 
Tabel 3 Correlatietabel van slaapproblemen met zelfrapportage (Zelf) en de subschaal Slaapproblemen van de SCL-90-R-N ${ }^{a}$ (SLA), totale schaal Psychoneuroticisme van de SCL-90-R-NLa (PSY), subschaal Depressie van de $D_{A S S^{b}}(D E P)$, subschaal Angst van de DASS ${ }^{b}$ (ANG) en subschaal Stress van de DASS ${ }^{b}$ (STR) $(n=149)$

\begin{tabular}{|c|c|c|c|c|c|c|}
\hline & Zelf & SLA & PSY & DEP & ANG & STR \\
\hline Zelf & I & $-.31 * *$ & $-.22 * *$ & $-.17 *$ & $-.18^{*}$ & -.06 \\
\hline SLA & & $\mathrm{I}$ & $.69 * *$ & $.46^{* *}$ & $.40 * *$ & $.31 * *$ \\
\hline PSY & & & 1 & $.74 * *$ & $.64 * *$ & $.65^{* *}$ \\
\hline DEP & & & & I & $.66 * *$ & $.70 * *$ \\
\hline ANG & & & & & 1 & $.6 I^{* *}$ \\
\hline STR & & & & & & I \\
\hline
\end{tabular}

$* \mathrm{p}<.05$, eenzijdig getoetst; ** $\mathrm{p}<.01$, eenzijdig getoetst.

a Arrindell \& Ettema, 2005.

${ }^{b}$ De Beurs e.a., $200 \mathrm{l}$.

Tabel 4 Scores van verdachten die voorafgaand aan het assessment thuis hadden geslapen en in een politiecellencomplex hadden geslapen met betrekking tot psychisch welzijn (totale score Psychoneuroticisme van de SCL-90-R-NL en subschalen Depressie, Angst en Stress van de DASS) en slaapproblemen (zelfrapportage en de subschaal Slaapproblemen van de SCL-90-R-NL), met daarbij de resultaten van det-toetsen

\begin{tabular}{|c|c|c|c|}
\hline & $\begin{array}{l}\text { Thuis geslapen } \\
\mathrm{n}=\text { I } 5 \text { M (SD) }\end{array}$ & $\begin{array}{l}\text { Politiecellencom- } \\
\text { plex geslapen } \\
\text { n= I } 34 \text { M (SD) }\end{array}$ & $\begin{array}{l}\text { Verschillen thuis vs. } \\
\text { cellencomplex } \\
\text { geslapen t-toets }\end{array}$ \\
\hline \multicolumn{4}{|l|}{ Psychisch welzijn } \\
\hline Psychoneuroticisme & $126.27(32.09) *$ & I $54.00(47.83)^{*}$ & $t(22)=-3.00, p=.007 *$ \\
\hline Depressie & $6.27(5.44) *$ & $12.15(9.63)^{*}$ & $t(25)=-2.32, p=.022 *$ \\
\hline Angst & $3.87(5.57)^{*}$ & $9.75(7.43)^{*}$ & $t(23)=-4.38, p=.000 *$ \\
\hline Stress & $9.86(4.67)$ & $12.60(8.12)$ & $t(22)=-1.91, p=.068$ \\
\hline \multicolumn{4}{|l|}{ Slaapproblemen } \\
\hline Zelfrapportage & $7.27(2.63)^{*}$ & $4.45(2.63)^{*}$ & $t(147)=3.93, p=.000 *$ \\
\hline Subschaal SCL-90-NL & $5.60(2.4 I)$ & $6.76(3.00)$ & $t(147)=-1.45, p=.150$ \\
\hline
\end{tabular}

$* \mathrm{p}<.05$.

tabel 4. Een post-hocanalyse, met significantieniveau $\alpha=.05$ en effectgrootte $d=$. 80 , toonde een power van .83 met betrekking tot de voornoemde twee groepen. 


\section{Discussie}

De eerste veronderstelling was dat verdachten die in een politiecellencomplex verblijven een verminderd psychisch welzijn ervaren, hetgeen overeenkomt met de bevindingen. De verdachten die meededen aan dit onderzoek rapporteerden een hogere psychische lijdensdruk in vergelijking met de normgroep uit de gemiddelde Nederlandse bevolking. Hoewel, zoals eerder genoemd, fysieke condities in politiecellencomplexen meestal minder goed zijn dan in reguliere gevangenissen (Blaauw e.a., 1997), scoorden verdachten met betrekking tot psychische lijdensdruk evenwel vergelijkbaar met gedetineerden in reguliere gevangenissen. Dat geen verschil is gevonden, is niet direct te verklaren, daarvoor is nader onderzoek noodzakelijk. Verder vertoonden verdachten in politiecellencomplexen een verhoogde mate van depressiviteit, angst en stress ten opzichte van een steekproef uit de normale Nederlandse bevolking. Er waren voor deze kenmerken geen normgegevens voorhanden over een steekproef gedetineerden in Nederlandse gevangenissen. Hoewel hier geen een-op-eenvergelijking gemaakt kan worden met het onderzoek van Blaauw e.a. uit 1998 (zij gebruikten bijvoorbeeld een oudere versie van de Symptom Checklist), lijkt wel dat een groot aantal verdachten die in politiecellencomplexen verblijven een verminderd psychisch welzijn ervaren.

De tweede veronderstelling was dat verdachten in politiecellencomplexen een hogere mate van slaapproblemen ervaren. Deze hypothese werd eveneens bevestigd. Verdachten in politiecellencomplexen bleken, net als Nederlandse gedetineerden in reguliere gevangenissen, slechter te slapen in vergelijking met de normgroep van de normale Nederlandse bevolking.

De derde veronderstelling was dat psychisch welzijn van verdachten negatief samenhangt met slaapproblemen, hetgeen de resultaten leken te bevestigen. Zelfrapportage over de ervaren kwaliteit van slaap van de afgelopen nacht bleek significant (hoewel laag) te correleren met psychisch welzijn, opnieuw met uitzondering van stress.

De vierde veronderstelling was dat verdachten die voorafgaande aan het psychologisch onderzoek in een politiecel hadden geslapen een verminderd psychisch welzijn en meer slaapproblemen ervaren dan verdachten die thuis hadden geslapen. Inderdaad scoorden verdachten die voorafgaand aan het psychologisch onderzoek in de cel hadden geslapen met betrekking tot psychisch welzijn significant lager en gaven zij de kwaliteit van slaap voorafgaand aan het testonderzoek een cijfer van 4,5, terwijl verdachten die thuis hadden geslapen een beter psychisch welzijn rapporteerden en hun slaap een cijfer van 7,3 gaven. Er werd geen verschil tussen deze twee groepen gevonden ten aanzien van de kwaliteit van slaap gemeten met de SCL-90-R-NL. Een mogelijke verklaring daarvoor is dat de zelf geconstrueerde zelfrapportage-items over de kwaliteit van slaap betrekking hadden op de voorafgaande nacht van het psychologisch onderzoek, terwijl de items van de SCL-90-R-NL betrekking hadden op de afgelopen zeven dagen inclusief de dag van het psychologisch onderzoek. Tevens werd tussen deze twee groepen wel verschil gevonden met betrekking tot depressie en angst, maar niet met betrekking tot stress; nader onderzoek zou moeten uitwijzen wat daar de oorzaak 
van is. Hoewel de grootte van de groep verdachten die thuis had geslapen (relatief) klein was, zou desalniettemin met enige voorzichtigheid gesteld kunnen worden dat de resultaten de vierde hypothese lijken te ondersteunen.

Gelet op de in de inleiding beschreven omstandigheden in een politiecellencomplex lijken deze resultaten op het eerste gezicht op het intrappen van een open deur. Echter, zoals hierboven vermeld, kunnen een verminderd psychisch welzijn en slaapproblemen bij verdachten een negatieve invloed hebben op het politieverhoor. De politie zou er derhalve goed aan doen om het psychisch welzijn en de kwaliteit van slaap van verdachten die in politiecellencomplexen verblijven zo veel mogelijk te bevorderen.

Wellicht kunnen de richtlijnen van het Kwaliteitsinstituut voor de Gezondheidszorg (2004) daarbij behulpzaam zijn. Deze richtlijnen om de kwaliteit van de slaap te verbeteren schrijven onder andere voor om zo veel mogelijk storende omgevingsfactoren te voorkomen (met name geluid en licht) en om te zorgen voor een comfortabel bed en beddengoed, voldoende ventilatie en een omgevingstemperatuur lager dan 24 graden Celsius.

Daarnaast kunnen simpele en relatief goedkope maatregelen vanuit onderzoek uit de omgevingspsychologie met betrekking tot zogenaamde healing environments worden gebruikt (Huisman e.a., 2012). Steeds vaker worden bij de (ver)bouw van ziekenhuizen en psychiatrische instellingen, onder andere, natuurelementen aangebracht (planten, of een afbeelding van natuur), wordt nauwkeurig gekeken naar kleuren en kunstlicht, en wordt gezorgd voor zo veel mogelijk daglicht en uitzicht naar buiten om het bioritme zo min mogelijk te verstoren (Bell e.a., 2001; Dalke e.a., 2006; Dijkstra e.a., 2006; Frumkin, 2001; Karlin \& Zeiss, 2006; Ulrich, 1991; 2000). Healing environments zijn effectief gebleken om slaapproblemen en gevoelens van stress, angst en depressie bij ziekenhuispatiënten te verminderen, met als gevolg een beter psychisch welzijn, een korter verblijf in het ziekenhuis en kostenbesparingen, en bovendien een lager ziekteverzuim en verhoogde arbeidssatisfactie onder personeel (Huisman e.a., 2012; Morris e.a., 2012; Nurse e.a., 2003; Steinke, 1991; Ulrich, 2001).

Ook worden separatiecellen bij psychiatrische eerstehulpinstanties steeds vaker omgebouwd tot zogenaamde comfortrooms, omdat het verblijf in een separatiecel tegenwoordig als potentieel traumatiserend wordt beschouwd (Van Steenbergen \& Pinedo, 2016). Een comfortroom is een kamer speciaal voor onrustige en geagiteerde patiënten, waardoor aversieve symptomen (zoals pijn, angst, onrust en hallucinaties) afnemen en escalatie van gedrag kan worden voorkomen. Een comfortroom is huiselijk en gezellig ingericht, en is bijvoorbeeld voorzien van comfortabel meubilair, rustige muziek en rustgevende kleuren (Souverijn, 2009).

\section{Beperkingen van het onderzoek}

Een beperking van dit onderzoek is dat slaapproblemen slechts werden vastgesteld met de subschaal Slaapproblemen van de SCL-90-R-NL en met één vraag aan de verdachten over hun slaapkwaliteit. Het was in het huidige onderzoek niet mogelijk om psychofysiologische metingen te verrichten om, naast slaapproblemen, het daadwerkelijke aantal uren van slaap te kunnen vaststellen. Een andere beperking is dat slaapproblemen bij verdachten niet alleen veroorzaakt kunnen 
worden door de omstandigheden in het politiecellencomplex, maar ook door intrapersoonlijke factoren, zoals medicijnen en drugs- en/of alcoholgebruik (of abstinentie van deze middelen). Ook dat was niet te verifiëren vanwege het ontbreken van exacte gegevens. Verder hadden, zoals hierboven opgemerkt, de items van twee instrumenten (SCL-90-R-NL en DASS) niet alleen betrekking op de dag/ nacht voorafgaand aan het psychologisch onderzoek, maar op de gehele week daarvoor. Daarom zou toekomstig onderzoek gebruik kunnen maken van instrumenten die het psychisch welzijn op het moment van het psychologisch onderzoek meten, zoals de Korte Klachten Lijst (Lange \& Appelo, 2007). Het was echter niet mogelijk om de testbatterij verder uit te breiden met dergelijke instrumenten vanwege de beperkte afnameduur. Bovendien werd voor de SCL-90-R-NL en DASS gekozen om een vergelijking met normgroepen mogelijk te maken. Tot slot moet worden opgemerkt dat de groep die voorafgaand aan het psychologisch onderzoek thuis had geslapen relatief klein was $(n=15)$ en dat de resultaten met de nodige voorzichtigheid moeten worden geïnterpreteerd.

\section{Conclusie}

Verdachten die in een politiecellencomplex hebben geslapen, rapporteren een verminderd psychisch welzijn en ervaren meer slaapproblemen dan zij die thuis hebben geslapen. Bovendien blijken hun slaapproblemen negatief samen te hangen met hun psychisch welzijn. Verder onderzoek naar de inrichting en omstandigheden in politiecellencomplexen, met als doel psychisch welzijn bij verdachten te bevorderen en slaapproblemen te verminderen, is aan te bevelen - niet alleen vanuit humaan perspectief, maar zeker ook met het oog op het opsporingsonderzoek en het politieverhoor.

\section{Literatuur}

Altman, I. (1975). The environment and social behavior: privacy, personal space, territoriality, and crowding. Monterey: Brooks/Cole.

Altman, I. \& Rogoff, B. (1987). World views in psychology and environmental psychology: trait, interactional, organismic and transactional perspectives. In: I. Altman \& D. Stokols (eds.). Handbook of environmental psychology. New York: Wiley, 245-281.

Arrindell, W.A. \& Ettema, J.H.M. (2005). Symptom Checklist SCL-90: handleiding bij een multidimensionale psychopathologie-indicator. Amsterdam: Pearson.

Baksheev, G.N., Thomas, S.D.M. \& Ogloff, J.R.P. (2012). Psychopathology in police custody: the role of importation, deprivation and interaction models. International Journal of Forensic Mental Health, 11(1), 24-32.

Bell, P.A., Greene, Th.C., Fisher, J.D. \& Baum, A. (2001). Environmental psychology. New York: Taylor \& Francis Group.

Beurs, E. de, Dyck, R. van, Marquenie, L.A., Lange, A. \& Blonk, R.W.B. (2001). De DASS: een vragenlijst voor het meten van depressie, angst en stress. Gedragstherapie, 34(1), 35-53.

Blaauw, J.A., Kerkhof, A. \& Vermunt, R. (1998). Psychopathology in police custody. International Journal of Law and Psychiatry, 21(1), 73-87. 
Blaauw, J.A., Vermunt, R. \& Kerkhof, A. (1997). Detention circumstances in police stations: towards setting the standards. Policing and Society, 7(1), 45-69.

Blagrove, M. (1996). Effects of length of sleep deprivation on interrogative suggestibility. Journal of Experimental Psychology: Applied, 2(1), 48-59.

Dalke, H., Little, J., Niemann, E., Camgoz, N., Steadman, G., Hill, S. \& Stott, L. (2006). Colour and lighting in hospital design. Optics \& Laser Technology, 38(4), 343-365.

Deetman, W., Draijer, N., Kalbfleisch, P., Merckelbach, H., Monteiro, M. \& Vries, G. de (2011). Seksueel misbruik van minderjarigen in de rooms-katholieke kerk. Amsterdam: Uitgeverij Balans.

Derogatis, L.R. (1977). SCL-90-R: administration, scoring and procedures manual for the R(evised) version. Baltimore: John Hopkins University.

Dijkstra, K., Pieterse, M.E. \& Pruyn, A.Th.H. (2006). Physical environmental stimuli that turn healthcare facilities into healing environments through psychologically mediated effects: systematic review. Journal of Advanced Nursing, 56(2), 166-181.

Dijkstra, K., Pieterse, M.E. \& Pruyn, A.Th.H. (2008). Individual differences in reactions towards color in healthcare environments. The role of stimulus screening ability. Journal of Environmental Psychology, 28, 268-277.

Drahota, A., Ward, D., Mackenzie, H., Stores, R., Higgins, B., Gal, D. \& Dean, T.P. (2012). Sensory environment on health-related outcomes of hospital patients (review). The Cochrane Library, 14(3), 1-361.

Faul, F., Erdfelder, E., Lang, A.G. \& Buchner, A. (2007). G*Power 3: a flexible statistical power analysis program for the social, behavioral, and biomedical sciences. Behavior Research Methods, 39, 175-191.

Field, A. (2012). Bonferroni correcting lots of correlations. Retrieved from https://www. methodspace.com/bonferroni-correcting-lots-of-correlations/.

Frenda, S.J., Berkowitz, S.R., Loftus, E.F. \& Fenn, K.M. (2016). Sleep deprivation and false confessions. Proceedings of the National Academy of Sciences, 113(8), 2047-2050.

Frumkin, H. (2001). Beyond toxicity: human health and the natural environment. Annual Journal of Preventive Medicine, 20(3), 234-240.

Gifford, R., Steg, L. \& Reser, J.P. (2011). Environmental psychology. In: P.R. Martin, F.M. Cheung, M.C. Knowles, M. Kyrios, J.B. Overmier \& J.M. Prieto, IAAP Handbook of applied psychology. Chichester: Wiley-Blackwell, 440-470.

Gudjonsson, G.H. (2003). The psychology of interrogations and confessions. A handbook. Chichester: Wiley.

Hagens, M. (2011). Toezicht op menswaardige behandeling van gedetineerden in Europa. Een onderzoek naar de verhouding tussen het EHRM en het CPT bij de effectuering van het folterverbod. Nijmegen: Wolf Legal Publishers.

Hancock, Ph. \& Jewkes, Y. (2011). Architectures of incarceration: the spatial pains of imprisonment. Punishment \& Society, 13(5), 611-629.

Harrison, Y. \& Horne, J.A. (2000). The impact of sleep deprivation on decision making: a review. Journal of Experimental Psychology: Applied, 6(3), 236-249.

Huisman, E.R.C.M., Morales, E., Hoof, J. van \& Kort, H.S.M. (2012). Healing environment: a review of the impact of physical environmental factors on users. Building and Environment, 58, 70-80.

Inspectie Veiligheid en Justitie (2015). Arrestantenzorg Nederland. Landelijke rapportage. Den Haag: Ministerie van Veiligheid en Justitie.

Karlin, B.E. \& Zeiss, R.A. (2006). Environmental and therapeutic issues in psychiatric hospital design: towards best practices. Psychiatric Services, 57(10), 1376-1378.

Killgore, W.D.S., Balkin, Th.J. \& Wesensten, N.J. (2006). Impaired decision making following $49 \mathrm{~h}$ of sleep deprivation. Journal of Sleep Research, 15(1), 7-13. 
Kwaliteitsinstituut voor de Gezondheidszorg (2004). Richtlijn Zorg bij een verstoord slaapwaak ritme. Utrecht: $\mathrm{CBO}$.

Lange, A. \& Appelo, M. (2007). De Korte Klachten Lijst, KKL. Handleiding. Houten: Bohn Stafleu van Loghum.

Lovibond, S.H. \& Lovibond, P.F. (1995). Manual for the Depression Anxiety Stress Scales. Sydney: The Psychology Foundation of Australia.

Merckelbach, H., Smeets, T. \& Jelicic, M. (2008). Onwaarschijnlijke symptomen simuleren: de Wildman Symptom Checklist. Neuropraxis, 12(2), 53-57.

Merckelbach, H., Langeland, W., Vries, G. de \& Draijer, N. (2014). Symptom overreporting obscures the dose-response relations between trauma severity and symptoms. Psychiatry Research, 217(3), 215-219.

Morris, R.G. \& Worrall, J.L. (2010). Prison architecture and inmate misconduct: a multilevel assessment. Crime \& Delinquency, 60(7), 1-27.

Morris, R.G., Carriaga, M.L., Diamond, B., Leeper Piquero, N. \& Piquero, A.R. (2012). Does prison strain lead to prison misbehavior? An application of general strain theory to inmate misconduct. Journal of Criminal Justice, 40(3), 194-201.

Nurse, J., Woodcock, P. \& Ormsby, J. (2003). Influence of environmental factors on mental health within prisons. Focus group study. British Medical Journal, 327(7413), 480-483.

Souverijn, A. (2009). Een comfortroom voor psychiatrische patiënten. Tijdschrift voor Verpleegkundigen, 11(12), 62-65.

Steinke, P. (1991). Using situational factors to predict types of prison violence. Journal of Offender Rehabilitation, 17(1), 119-132.

Thomas, M., Sing, H., Belenky, G., Holcomb, H., Mayberg, H. et al. (2000). Neural basis of alertness and cognitive performance impairments during sleepiness. Effects of $24 \mathrm{~h}$ of sleep deprivation on waking human regional brain activity. Journal of Sleep Research, 9(4), 335-352.

Ulrich, R.S. (1991). Effects of interior design on wellness: theory and recent scientific research. Journal of Health Care Interior Design, 3(1), 97-109.

Ulrich, R.S. (2000). Effects of healthcare environmental design on medical outcomes. In: Design and health. Proceedings of the Second International Conference on Health and Design. Stockholm: Svensk Byggtjanst, 49-59.

Van Steenbergen, E. \& Pinedo, D. (2016, 3 september). Isoleercel: van kaal hok tot comfortroom. NRC. Geraadpleegd op https://www.nrc.nl/nieuws/2016/09/03/isoleercel-vankaal-hok-tot-comfortroom-4108097-a1519431.

Watson, D., Clark, L.A. \& Carey, G. (1988). Positive and negative affectivity and their relation to anxiety and depressive disorders. Journal of Abnormal Psychology, 97(3), 346-353.

Wildman, R.W. \& Wildman, R.W., Jr. (1999). The detection of malingering. Psychological Reports, 84(2), 386-388.

Wohlwill, J.F. (1966). The physical environment: a problem for a psychology of stimulation. Journal of Social Issues, 22(4), 29-38. 